Monika Szturmowicz' ${ }^{1}$ Piotr Rudziński ${ }^{2}$, Aneta Kacprzak', Renata Langfort ${ }^{3}$, Iwona Bestry ${ }^{4}$, Beata Broniarek-Samson ${ }^{5}$, Tadeusz Orłowski

${ }^{1} I^{\text {st }}$ Department of Lung Diseases, National Institute of Tuberculosis and Lung Diseases Head: Prof. J. Kuś, MD, PhD

${ }^{2}$ Department of Thoracic Surgery, National Institute of Tuberculosis and Lung Diseases Head: Prof. T. Orłowski, MD, PhD

${ }^{3}$ Department of Patomorphology, National Institute of Tuberculosis and Lung Diseases

Head: R. Langfort, MD

${ }^{4}$ Department of Radiology, National Institute of Tuberculosis and Lung Diseases

Head: I. Bestry, MD

${ }^{5}$ ALAB Laboratories

\title{
Prognostic value of serum C-reactive protein (CRP) and cytokeratin 19 fragments (Cyfra 21-1) but not carcinoembryonic antigen (CEA) in surgically treated patients with non-small cell lung cancer
}

\author{
Znaczenie rokownicze surowiczego stężenia białka C-reaktywnego (CRP) \\ i fragmentów cytokeratyny 19 (Cyfra 21-1), ale nie antygenu rakowopłodowego (CEA) \\ u chorych leczonych operacyjnie z powodu niedrobnokomórkowego raka płuca
}

The authors declare no financial disclosure

\section{Abstract}

Introduction: The aim of the study was to assess the prognostic value of cytokeratin 19 fragments (Cyfra 21-1), carcinoembryonic antigen (CEA) and C-reactive protein (CRP) in surgically treated NSCLC patients.

Material and methods: 50 NSCLC patients (25 adenocarcinoma, 21 squamous cell and 4 adenosquamous), clinical stages I and II, age 42-89 years, entered the study. CEA, Cyfra 21-1 and CRP concentrations were measured in serum taken before surgery, CEA and Cyfra 21-1 in 50 patients, CRP — in 46 patients. The survival was calculated from the date of surgical treatment until death or until the end of the observation time. The results were expressed as medians $(95 \% \mathrm{Cl})$.

Results: Cyfra 21-1 concentration was $2.1(0.7-14.5) \mathrm{ng} / \mathrm{mL}$. Survival time in the patients with Cyfra $21-1 \leq 2 \mathrm{ng} / \mathrm{mL}$, and $>2 \mathrm{ng} /$ $/ \mathrm{mL}$ was 79 (14.85-88.2) and 29 (5.7-87.6) months, $(p<0.026)$. CEA concentration was $2.68(0.87-72.7) \mathrm{ng} / \mathrm{mL}$, significantly higher in adenocarcinoma than in squamous cell lung cancer $-4.38 \mathrm{ng} / \mathrm{mL}(1.67-41.35) \mathrm{vs} .2 .2 \mathrm{ng} / \mathrm{mL}(1.0-6.1), \mathrm{p}=0.002$. CRP concentration was $5.45(0-122.6) \mathrm{mg} / \mathrm{L}$. Significant dependence was found between CRP and pathological tumour size (pT). Median CRP values in pT1, pT2 and pT3+4 tumours were: $2.8 \mathrm{mg} / \mathrm{L}, 6.9 \mathrm{mg} / \mathrm{L}$ and $23.5 \mathrm{mg} / \mathrm{L}$, respectively. Survival time of the patients with CRP $\leq 10 \mathrm{mg} / \mathrm{L}$ and CRP $>10 \mathrm{mg} / \mathrm{L}$ was 79 (14.85-88.2) and 29.5 (5.7-87.6) months, respectively $(p=0.045) . \mathrm{CRP}>10 \mathrm{mg} / \mathrm{L}$ and Cyfra 21-1 $>2 \mathrm{ng} / \mathrm{mL}$ were the only significant preoperative prognostic indicators (HR 2.08 and 2.04, respectively). Among the postoperative parameters, pathological stage of disease (p-stage) and pT were the significant prognostic indicators (HR 2.1 and 2.42, respectively). Conclusions: In the present study, concerning surgically treated NSCLC patients, preoperative CRP > $10 \mathrm{mg} / \mathrm{L}$ and Cyfra 21-1 > $2 \mathrm{ng} / \mathrm{mL}$ were the only negative prognostic indicators, while $\mathrm{pT}$ and $\mathrm{p}$-stage were significant postoperative prognostic indicators.

Key words: non-small cell lung cancer, prognosis, cytokeratins, carcinoembryonic antigen, c-reactive protein, surgical treatment

Pneumonol. Alergol. Pol. 2014; 82: 422-429

Address for correspondence: Prof. dr hab. n. med. Monika Szturmowicz MD, PhD, I Department of Lung Diseases, National Institute of Tuberculosis and Lung Diseases, tel.: + 482243121 77, e-mail: monika.szturmowicz@gmail.com

DOI: 10.5603/PiAP.2014.0055

Praca wpłynęła do Redakcji: 22.04.2014 r.

Copyright (C) 2014 PTChP

ISSN 0867-7077 


\section{Streszczenie}

Wstęp: Celem pracy była ocena znaczenia rokowniczego przedoperacyjnych stężeń : fragmentów cytokeratyny 19 (Cyfra 21-1), antygenu rakowo-płodowego (CEA) i biatka C-reaktywnego (CRP) w surowicy u chorych operowanych z powodu NDRP.

Materiat i metody: Badaniem objęto 50 chorych, w wieku 42-89 lat, w I i II klinicznym stadium zaawansowania NDRP, 25 chorych na gruczolakoraka, 21 na raka płaskonabłonkowego i 4 na raka gruczołowo-płaskonabłonkowego. Stężenie CEA, Cyfra 21-1 i CRP oceniano w surowicy pobranej przed zabiegiem operacyjnym: CEA i Cyfra 21-1 — u 50 chorych, CRP — u 46 chorych. Czas przeżycia mierzono od daty zabiegu do zgonu lub do końca obserwacji. Wyniki podawano jako mediany (95\% Cl).

Wyniki: Stężenie Cyfra 21-1 wynosiło 2,1 $(0,7-14,5) \mathrm{ng} / \mathrm{ml}$. Czas przeżycia chorych z Cyfra 21-1 $\leq 2 \mathrm{ng} / \mathrm{ml} \mathrm{i}>2 \mathrm{ng} / \mathrm{ml}$ wynosił odpowiednio: $79(14,85-88,2)$ i $29(5,7-87,6)$ miesiąca, $p<0,026$.

Stężenie CEA wynosiło 2,68 $(0,87-72,7) \mathrm{ng} / \mathrm{ml}$, i było istotnie wyższe u chorych na gruczolakoraka w porównaniu z chorymi na raka płaskonabłonkowego $-4,38(1,67-41,35)$ v. $2,2(1,0-6,0) \mathrm{ng} / \mathrm{ml}, \mathrm{p}=0,002$.

Stężenie CRP wynosito 5,45 (0-122,6) mg/l. Stwierdzono zależność pomiędzy CRP a patologicznym wymiarem guza. Mediana stężenia CRP w grupach pT1, pT2 i pT3+4 wynosiła odpowiednio: 2,8 mg/l, 6,9 mg/l and 23,5 mg/L (p < 0,05). Czas przeżycia chorych ze stężeniem CRP $\leq 10 \mathrm{mg} / \mathrm{l}$ i $>10 \mathrm{mg} / \mathrm{l}$ wynosił odpowiednio: $79(14,85-88,2)$ i 29,5 $(5,7-87,6)$ miesięcy $(p=0,045)$. CRP $>10 \mathrm{mg} / \mathrm{l}$ i Cyfra 21-1 > $2 \mathrm{ng} / \mathrm{ml}$ były jedynymi przedoperacyjnymi parametrami 0 istotnym znaczeniu rokowniczym (HR odpowiednio 2,08 i 2,42). Wśród parametrów pooperacyjnych istotne znaczenie rokownicze posiadały: stopień zaawansowania patologicznego NDRP i wymiar guza w badaniu patologicznym (HR 2,1 i 2,42).

Wnioski: W badanej grupie chorych na NDRP, spośród parametrów przedoperacyjnych tylko CRP > $10 \mathrm{mg} / \mathrm{l}$ i Cyfra 21-1 $>2 \mathrm{ng} / \mathrm{ml}$ były negatywnymi czynnikami rokowniczymi, spośród parametrów pooperacyjnych — wymiar guza i stopień zaawansowania patologicznego NDRP.

Słowa kluczowe: rak niedrobnokomórkowy, rokowanie, cytokeratyny, antygen rakowo-płodowy, białko C-reaktywne, leczenie operacyjne

Pneumonol. Alergol. Pol. 2014; 82: 422-429

\section{Introduction}

Surgical treatment in the early stage of non -small cell lung cancer (NSCLC) is associated with the best prognosis. Current 5-year survival rates are $50-70 \%$ in pathological stage I of the disease and $43-61 \%$ in stage II [1]. Despite extensive preoperative evaluation, still a significant proportion of the patients are diagnosed with pathological stage III disease after surgery. Such a finding is combined with substantially worse survival (5-year survival rates - 10-30\%), even with the use of adjuvant therapy [2].

Stage of the disease is the strongest prognostic indicator; nevertheless, other prognostic factors such as age, tumour histology, lymphatic and blood vessels involvement are described in the literature $[3,4]$.

The role of preoperative assessment of tumour markers and inflammatory proteins as prognostic indicators is still not established.

The aim of the present study was to assess the value of preoperative tumour markers [cytokeratin 19 fragments (Cyfra 21-1), carcinoembryonic antigen (CEA)] and C-reactive protein (CRP) in predicting long-term survival in surgically treated non-small cell lung cancer patients.

\section{Material and methods}

Fifty consecutive NSCLC patients referred in 2004 to the Department of Thoracic Surgery of the National Institute of Tuberculosis and Lung Diseases were prospectively enrolled into the study group. Written consent for participation in the study was obtained in all of them. The group included 38 males and 12 females, and median age was 65 years (range $42-89$ years). Histological types of tumours, according to WHO classification from 2004 [5], were as follows: adenocarcinoma - in 25 patients, squamous cell lung cancer - in 21, adenosquamous lung cancer - in 4 patients. Preoperative staging was based on chest and upper abdomen computed tomography (CT), fibre-optic bronchoscopy and abdomen ultrasonographic examination. Brain CT scan was performed in four patients due to clinical suspicion of CNS metastases - the results were negative in all of them. Mediastinoscopy was performed in six patients with the suspicion of $\mathrm{N} 2$ disease based on chest CT (mediastinal lymph nodes enlargement $>1 \mathrm{~cm}$ in the short axis). The results were negative in all of them. The clinical staging (including the negative result of mediastinoscopy), according to WHO sixth edition [6], 
was: Ia in 12 patients, Ib in 26 patients, IIa in 3 patients and IIb in 9 patients.

Surgical treatment consisted of the following: lobectomy in 42 patients, bilobectomy in 1 pt and pneumonectomy in 7 patients.

Pathological stage of the disease was as follows: Ia in 13 patients, Ib in 20, IIb in 9 patients, IIIa in 4, IIIb in 3 and IV (metastases to the other lobe) in 1 pt. Pathological tumour size (pT) was: pT1 in 13 patients, pT2 in 32, pT3 in 2, and pT4 in 3 patients.

The degree of differentiation of lung cancer was determined in 47 tumours: 14 were poorly differentiated (G3), 29 were moderately differentiated (G2) and 4 were well differentiated (G1). Mean ( \pm SD) and median (95\%CI) percentage of necrotic cells were $21.74 \% \pm 16.9 \%$ and $20 \%$ (0-80)\%, respectively.

The patients in whom pathological stages IIIa-IV of NSCLC were recognised after surgical treatment received adjuvant therapy (chemo \pm radiotherapy).

Carcinoembryonic antigen (CEA) and cytokeratin 19 fragment (Cyfra 21-1) concentrations were measured in serum taken before surgery and before mediastinoscopy. Cobas Core immunoassay was used. The cut-off values provided by the assay's manufacturer were applied: $5 \mathrm{ng} / \mathrm{mL}$ for CEA and $3.3 \mathrm{ng} / \mathrm{mL}$ for Cyfra 21-1. Serum CRP was assessed in 46 patients by Hitachi analyser. The cut off value was $5 \mathrm{mg} / \mathrm{L}$. The CEA, Cyfra 21-1 and CRP values with highest prognostic significance were identified with the use of ROC curves.

The survival time was calculated from the date of surgical treatment until death or until the end of observation time (five years).

Kruskal-Wallis one-way analysis of variance (on ranks) was used to compare marker values in different subgroups of patients. Death hazard ratio
(HR) was assessed with single and multiple regression analysis. $\mathrm{P}<0.05$ was considered significant.

\section{Results}

Median survival in the presented group of patients was 72.5 (4-108) months. The percentages of 1-, 2-, 3-, 4- and 5-year survival were: $88 \%$, $72 \%, 60 \%, 54 \%$ and 54\%, respectively.

Median preoperative serum Cyfra 21-1 concentration was 2.1 (95\%CI $0.7-14.5) \mathrm{ng} / \mathrm{mL}$. In 16/50 patients (32\%) Cyfra 21-1 values exceeded $3.3 \mathrm{ng} / \mathrm{mL}$. A tendency towards higher Cyfra 21-1 values in the patients with higher pathological stages of the disease, comparing to the patients with lower stages of the disease, was found (Table 1). Median Cyfra 21-1 in stages Ia-IIb was 2.03 (95\%CI 1-6.76) ng/mL, and in stages III-IV it was 3.6 (95\%CI 1-14.5) ng/mL ( $\mathrm{p}=0.1)$. The values of Cyfra 21-1 did not correlate with the histological type of tumour (Table 2) nor with the percentage of tumour necrosis. According to ROC analysis, the Cyfra 21-1 value with optimal prognostic significance was $2 \mathrm{ng} / \mathrm{mL}$. Median survival times in the patients with Cyfra 21-1 $<=2 \mathrm{ng} / \mathrm{mL}$ (23 patients) and $>2 \mathrm{ng} / \mathrm{mL}$ (27 patients) were 79 (95\%CI 14.85-88.2) months and 29 (95\%CI 5.7-87.6) months, respectively $(\mathrm{p}<0.026)$. The survival curves of the patients with Cyfra 21-1 $\leq$ $2 \mathrm{ng} / \mathrm{mL}$ and $>2 \mathrm{ng} / \mathrm{mL}$ are presented in Figure 1.

Median preoperative serum CEA concentration was 2.68 (95\%CI 0.87-72.7) ng/mL. CEA exceeding $5 \mathrm{ng} / \mathrm{mL}$ was found in 11/50 patients (22\%). CEA serum concentration depended on the histological type of tumour (Table 2). Significantly higher median serum CEA was found in the patients with adenocarcinoma, comparing to the patients with squamous cell lung cancer -4.38

Table 1. Cyfra 21-1, CEA and CRP according to the pathological stage of the disease in 50 NSCLC patients treated with surgery

\begin{tabular}{|c|c|c|c|c|}
\hline Factor & No & $\begin{array}{c}\text { Cyfra 21-1 (ng/mL) } \\
\text { Median (95\%Cl) }\end{array}$ & $\begin{array}{c}\text { CEA (ng/mL) } \\
\text { Median (95\%Cl) }\end{array}$ & $\begin{array}{c}\text { CRP (mg/L)* } \\
\text { Median (95\%Cl) }\end{array}$ \\
\hline \multicolumn{5}{|l|}{ p-stage } \\
\hline la & 13 & $1.8(0.75-3.5)$ & $2.8(1.4-15.02)$ & $2.8(0.06-60.99)$ \\
\hline $\mathrm{lb}$ & 20 & $2.16(1-10.45)$ & $2.58(0.94-24.4)$ & $9.4(1.49-74.78)$ \\
\hline Ilb & 9 & $1.93(1.3-5.77)$ & $2.6(1-72.7)$ & $12.4(0.2-86.3)$ \\
\hline Illa & 4 & $4.6(1-7.1)$ & $2.77(1.8-4.3)$ & $0.1(0-23.5)$ \\
\hline Illb & 3 & $2.9(1.8-14.5)$ & $1.5(1-3.3)$ & $50.8(2.4-122.6)$ \\
\hline IV & 1 & 2.61 & 9.57 & 6.9 \\
\hline la-Ilb & 42 & $2.03(1-6.76)$ & $2.68(1-30.18)$ & $5.45(0.36-76.1)$ \\
\hline III-IV & 8 & $3.6(1-14.5)$ & $2.72(1-9.57)$ & $4.65(0-122.6)$ \\
\hline $\mathrm{p}$ & & 0.1 & 0.54 & 0.5 \\
\hline
\end{tabular}


Table 2. Cyfra 21-1, CEA and CRP according to the histological type of tumour in 50 NSCLC patients

\begin{tabular}{ccccc}
\hline Histology & No patients & $\begin{array}{c}\text { Cyfra } \mathbf{2 1 - 1}(\mathbf{n g} / \mathbf{m L}) \\
\text { Median }(\mathbf{9 5 \%} \mathbf{C l})\end{array}$ & $\begin{array}{c}\text { CEA (ng/mL) } \\
\text { Median (95\% } \mathbf{C I})\end{array}$ & $\begin{array}{c}\text { CRP (mg/L)* } \\
\text { Median (95\%CI) }\end{array}$ \\
\hline Adeno & 25 & $2.0(1-5.22)$ & $4.38(1.67-41.35)$ & $4.7(0.42-83.99)$ \\
SCC & 21 & $2.35(1.1-13.8)$ & $2.2(1-6.1)$ & $17.15(0-99.88)$ \\
Others & 4 & $3.43(0.7-7.1)$ & $3.22(1.4-4.49)$ & $1.3(0.2-23.5)$ \\
$p$ & & 0.27 & 0.002 & 0.112 \\
\hline
\end{tabular}

*In 46 patients; CEA — carcinoembryonic antigen; CRP — C-reactive protein; NSCLC — non -small cell lung cancer; adeno — adenocarcinoma; SCC — squamous cell lung cancer

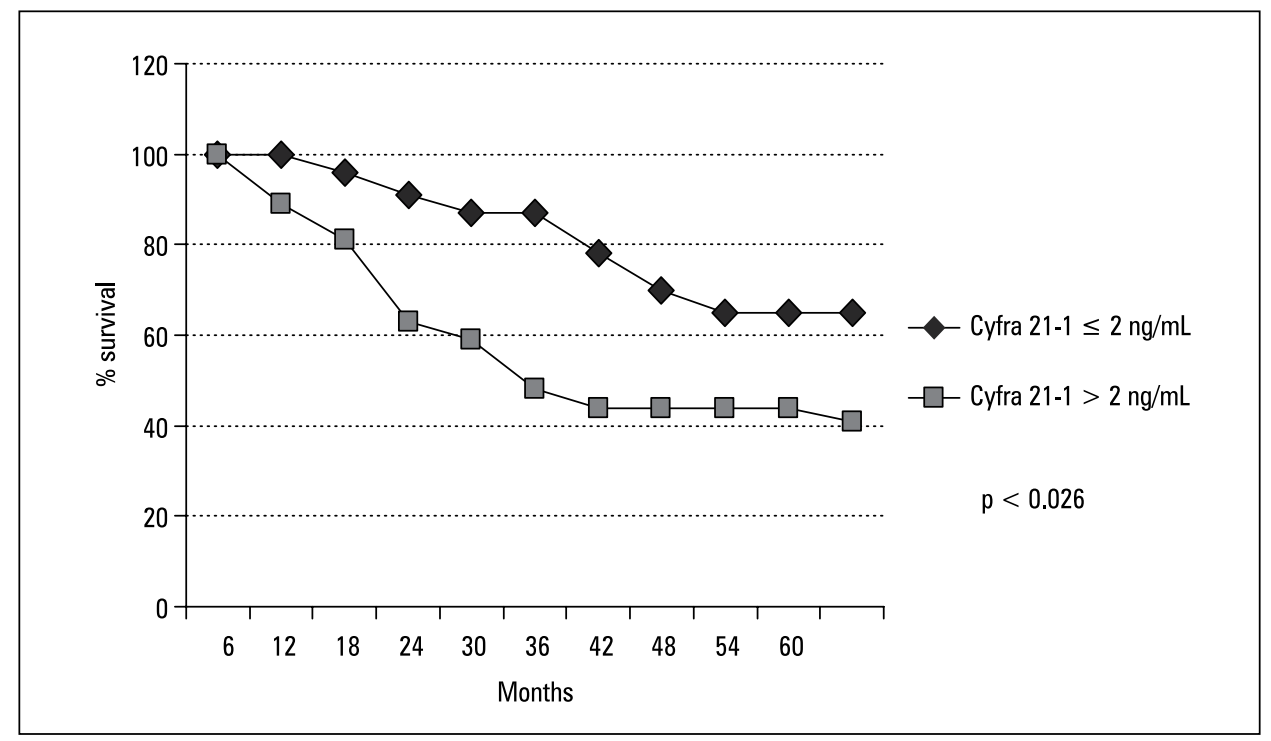

Figure 1. Prognostic significance of preoperative serum Cyfra 21-1 in 50 non -small cell lung cancer patients

$\mathrm{ng} / \mathrm{mL}(95 \% \mathrm{CI} 1.67-41.35)$ vs. $2.2 \mathrm{ng} / \mathrm{mL}$ (95\%CI 1.0-6.1), $\mathrm{p}=0.002$. No correlation was found between serum CEA and pathological stage of the disease (Table 1). ROC analysis failed to indicate an optimal prognostic CEA value.

Median serum CRP was 5.45 (95\%CI 0-122.6) $\mathrm{mg} / \mathrm{L}$. Values exceeding $5 \mathrm{mg} / \mathrm{L}$ were found in $26 / 46$ patients $(60 \%)$. Significant dependence was found between serum CRP and pathological tumour size (pT). Median CRP values in pT1, pT2 and pT3+4 tumours were: $2.8 \mathrm{mg} / \mathrm{L}, 6.9 \mathrm{mg} / \mathrm{L}$ and $23.5 \mathrm{mg} / \mathrm{L}$, respectively ( $\mathrm{p}<0.05$ ) (Table 3 ).

ROC analysis revealed that CRP $>10 \mathrm{mg} / \mathrm{L}$ was the optimal prognostic cut-off value. Median survival time of 28 patients with CRP $\leq 10 \mathrm{mg} / \mathrm{L}$ was 79 (14.85-88.2) months, and for 18 patients with CRP > $10 \mathrm{mg} / \mathrm{L}$ it was 29.5 (5.7-87.6) months $(\mathrm{p}=0.046)$. Survival curves of the patients with serum CRP $\leq 10 \mathrm{mg} / \mathrm{L}$ and $>10 \mathrm{mg} / \mathrm{L}$ are presented in Figure 2.

Univariate analysis revealed that out of the factors known before lung surgery, only serum CRP $>10 \mathrm{mg} / \mathrm{L}$ and Cyfra 21-1 exceeding $2 \mathrm{ng} / \mathrm{mL}$ were significant prognostic indicators. No prognostic significance for patient age, sex, histological type of tumour and clinical stage of disease was found (Table 4). Among the parameters known after surgical treatment, pathological stage of the disease and $\mathrm{pT}$ value were significant prognostic indicators (Table 4). No prognostic significance of the percentage of necrotic tumour cells and the degree of tumour differentiation was found.

Multivariate analysis taking into account only pretreatment prognostic parameters (Cyfra 21-1 > $2 \mathrm{ng} / \mathrm{mL}$ and $\mathrm{CRP}>10 \mathrm{mg} / \mathrm{L}$ ) revealed that none of the markers was an independent prognostic factor. Multivariate analysis taking into account all significant prognostic variables, both pretreatment and post-treatment, revealed that only pathological stage of disease was an independent prognostic indicator (Table 4).

\section{Discussion}

CRP is a marker of inflammation and tissue damage. Its prognostic significance is well esta- 
Table 3. CRP according to pathological size of tumour in 46 NSCLC patients

\begin{tabular}{ccccc}
\hline Factor & No patients & Median CRP $\mathbf{~ m g} / \mathbf{L}$ & Range $\mathbf{~ m g} / \mathbf{L}$ & CRP $>$ 10 $\mathbf{~ m g} / \mathbf{L}$ \\
\hline pT1 & 12 & $2.8^{*}$ & $0.06-60.99$ & $2 / 12$ \\
pT2 & 29 & $6.9^{*}$ & $0-83.17$ & $12 / 29$ \\
pT3+4 & 5 & $23.5^{*}$ & $2.4-122.6$ & $4 / 5$ \\
\hline
\end{tabular}

${ }^{*} p<0.05$; CEA — carcinoembryonic antigen; CRP — C-reactive protein; NSCLC — non-small cell lung cancer; pT — pathological tumour size

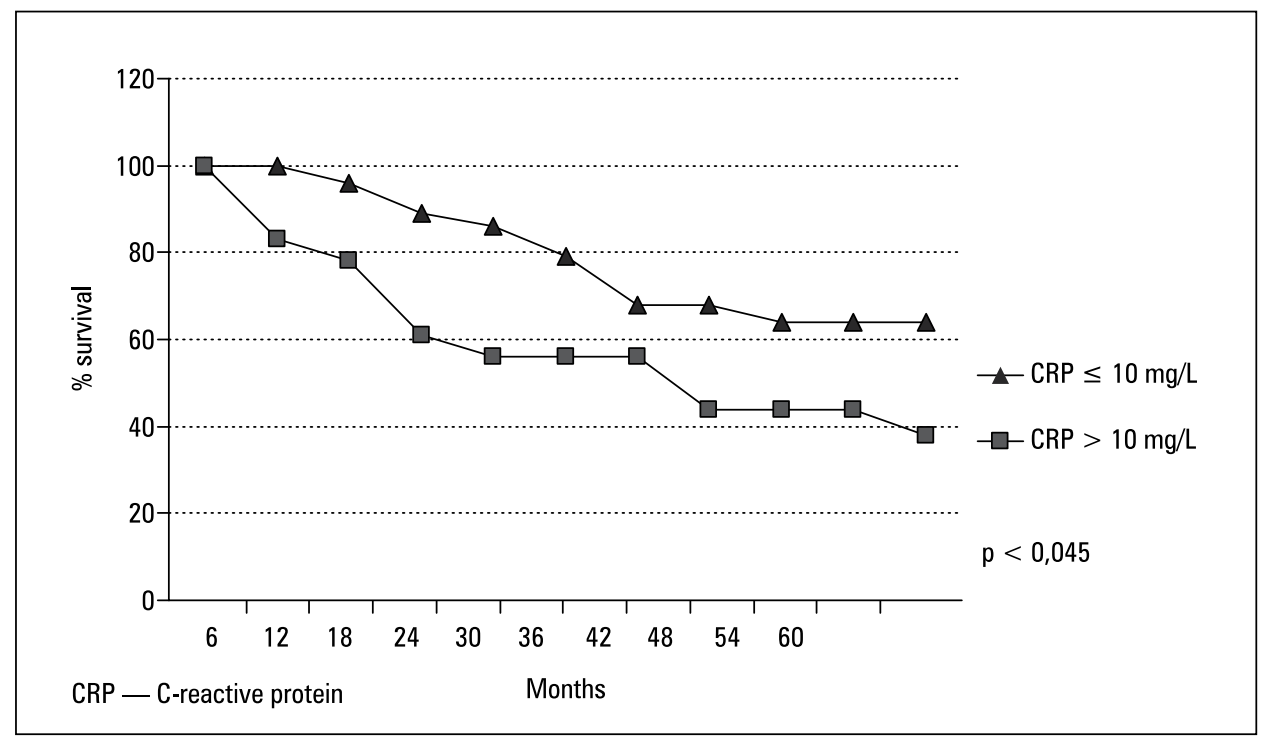

Figure 2. Prognostic significance of preoperative serum C-reactive protein in 46 non-small cell lung cancer patients

blished in cardiovascular diseases [7]. Shields et al. found that inflammation score assessed by CRP, b-cell attracting chemokine 1 (macrophage -derived chemokine) and interleukin 1 receptor antagonist provided good separation in 10-year lung cancer cumulative risk among current and former smokers and was of prognostic significance [8].

A large epidemiological study of 33,567 participants with various neoplastic diseases conducted by Ko et al. [9] indicated that CRP $\geq 3 \mathrm{mg} / \mathrm{L}$ was associated with higher mortality in lung cancer.

In the present study, preoperative serum CRP concentration $>10 \mathrm{mg} / \mathrm{L}$ was of prognostic significance, and the risk of death was twice as high in the group of patients with CRP $>10 \mathrm{mg} / \mathrm{L}$ comparing to the others. A similar observation concerning CRP prognostic value was made by O'Dowd et al. [10], who found significantly worse survival in patients with CRP exceeding $10 \mathrm{mg} / \mathrm{L}$ comparing to those with CRP equal to or lower than $10 \mathrm{mg} / \mathrm{L}$ (26.2 months and 75.9 months, respectively). Hara et al. [11] found the prognostic significance of CRP $>5 \mathrm{mg} / \mathrm{L}$ in 203 patients who had undergone a curative resection of NSCLC. Tomita et al. [12] found in 301 resectable NSCLC patients that combined use of CRP and neutrophil-to-lymphocyte index could discriminate the groups with different 5-year survival rates (74.18\% in case of both values low vs. $20 \%$ in case of both values high). Alifano et al. [13] found preoperative CRP exceeding $20 \mathrm{mg} / \mathrm{L}$ to be a significant prognostic indicator in 300 stage I or II NSCLC patients treated with surgery.

Searching for a possible reason for the prognostic significance of CRP in NSCLC, we found in the present study a significant dependence between serum CRP and the pathological size of the tumour. Lee et al. [14] found a correlation between CRP and pathological tumour diameter, as well as between CRP and the signs of lymphovascular invasion, in 102 patients who underwent pulmonary resection. Alifano et al. found in lung cancer patients a correlation between serum CRP and the presence of chronic bronchitis, hypoalbuminaemia, pathologic stage of the disease and peritumoural vascular emboli. 
Table 4. Prognostic significance of different variables in 50 NSCLC patients (univariate and multivariate analysis)

\begin{tabular}{|c|c|c|}
\hline Univariate analysis & HR & $\mathbf{p}$ \\
\hline CRP* & 2,339 & 0.024 \\
\hline $\mathrm{CRP}>10 \mathrm{mg} / \mathrm{L}^{*}$ & 2.08 & 0.043 \\
\hline $\mathrm{CRP}>20 \mathrm{mg} / \mathrm{L}^{*}$ & 2.137 & 0.038 \\
\hline Cyfra 21-1 & 1.402 & 0.167 \\
\hline Cyfra 21-1 > $2 \mathrm{ng} / \mathrm{mL}$ & 2.04 & 0.046 \\
\hline CEA & 1.17 & 0.25 \\
\hline CEA $>5 \mathrm{ng} / \mathrm{mL}$ & 0.46 & 0.647 \\
\hline C-stage & 0.86 & 0.39 \\
\hline P-stage la-Ilb vs. III-IV & 2.7 & 0.009 \\
\hline P-stage la, Ib vs. Ilb vs III-IV & 2.1 & 0.04 \\
\hline P-stage & 2.1 & 0.041 \\
\hline $\mathrm{p}-\mathrm{T}$ & 2.42 & 0.019 \\
\hline Histological type & 1.39 & 0.17 \\
\hline Age & 0.74 & 0.46 \\
\hline Gender & 1.17 & 0.248 \\
\hline$\%$ of tumour necrosis & 0.37 & 0.7 \\
\hline G1 vs. G2 vs. G3 & 0.275 & 0.785 \\
\hline $\begin{array}{l}\text { Multivariate analysis } \\
\text { (preoperative factors) }\end{array}$ & $\mathrm{HR}$ & $\mathrm{p}$ \\
\hline $\mathrm{CRP}>10 \mathrm{mg} / \mathrm{L}$ & 1.39 & 0.173 \\
\hline Cyfra 21-1 > $2 \mathrm{ng} / \mathrm{mL}$ & 1.52 & 0.136 \\
\hline $\begin{array}{l}\text { Multivariate analysis } \\
\text { (all prognostic factors)* }\end{array}$ & $\mathrm{HR}$ & $\mathrm{p}$ \\
\hline $\mathrm{CRP}>10 \mathrm{mg} / \mathrm{L}$ & 1.73 & 0.09 \\
\hline Cyfra 21-1 > $2 \mathrm{ng} / \mathrm{mL}$ & 1.03 & 0.31 \\
\hline p-Stage la-Ilb vs. III-IV & 2.65 & 0.01 \\
\hline
\end{tabular}

The other prognostic indicator found by our group was preoperative serum Cyfra 21-1 exceeding $2 \mathrm{ng} / \mathrm{mL}$. Median survival in the groups with Cyfra $21-1<2 \mathrm{ng} / \mathrm{mL}$ and $>2 \mathrm{ng} / \mathrm{mL}$ were 79 (95\%CI 14.85-88.2) months and 29 (95\%CI $5.7-87.6)$ months, respectively $(p<0.026)$. Univariate analysis revealed that the risk of death in the patients with serum Cyfra 21-1 > $2 \mathrm{ng} /$ $/ \mathrm{mL}$ was twice as high as for those with Cyfra 21-1 $\leq 2 \mathrm{ng} / \mathrm{mL}$.

The prognostic value of Cyfra 21-1 was investigated by many authors, and most of them confirmed the negative prognostic significance of abnormal Cyfra 21-1 value [15-20] (Table 5). In the reports concerning early-stage NSCLC treated with surgical resection, Cyfra 21-1 cut-offs used for assessment of prognosis were usually 2-2.8 $\mathrm{ng} / \mathrm{mL}[18,19]$, and so were comparable to our cut off value of $2 \mathrm{ng} / \mathrm{mL}$. The prognostic cut off value of Cyfra 21-1 in unresectable NSCLC was found to be much higher (4- $18 \mathrm{ng} / \mathrm{mL})[21,22]$.

Cyfra 21-1 was previously described as a marker of squamous cell lung cancer (SCC) [23]. Subsequently, an elevated level of the marker was also found in serum of patients with adenocarcinoma and small cell lung cancer [22]. Similarly, in the present study we did not demonstrate significant differences between adenocarcinoma and SCC with respect to Cyfra 21-1 serum levels.

An interesting study concerning the origin of Cyfra 21-1 in serum was presented Kosacka et al. [24], who compared tumour cytokeratin 19 immunostaining with Cyfra 21-1 value in serum in each of the studied patients. The authors found that the lower the Cyfra 21-1 in tumour tissue, the higher it was in serum. This finding confirms early observations that Cyfra 21-1 is released into circulation from necrotic tumour cells. Hanada et al. [25] found that the combination of weak cytokeratin 19 tumour expression and high serum Cyfra 21-1 levels was a predictor of poorer prognosis in 107 SCC patients.

These data may indicate that Cyfra 21-1 serum level reflects mainly the degree of tumour necrosis. Nevertheless, we could not demonstrate a correlation between serum Cyfra 21-1 and the percentage of tumour necrotic cells in the presented group of patients.

In the present study, we did not find the prognostic significance of preoperative serum CEA. One of the reasons was that elevated CEA was found also in the patients with early-stage tumours (mainly of adenocarcinoma histology), who survived five years from surgical resection without a relapse. The other reason for the lack of prognostic significance of CEA in our study was probably the small number of patients enrolled.

Most published data indicate the prognostic significance of CEA (Table 6) [26-33], but the majority of reports concern groups of patients with adenocarcinoma [28, 32] or with substantial adenocarcinoma predominance [18, 29, 31]. The authors of recently published articles have found that increased CEA concentration is a significant predictor of $\mathrm{pN} 2$ disease [1], tumour diameter and visceral pleural invasion [34], as well as recurrence after surgery [35]. Tomita et al. [36] described the combination of high CEA and SUV max > 6.6 on PET-CT scan as a prognostic variable. 
Table 5. Prognostic value of Cyfra 21-1 according to published data

\begin{tabular}{|c|c|c|c|c|c|}
\hline Author & Study group & Histology & $\begin{array}{c}\text { Cyfra 21-1 cut off } \\
n g / m L\end{array}$ & 5 years survivors & $\mathbf{p}$ \\
\hline Reinmuth 2002 [15] & $\begin{array}{c}67 \text { NSCLC } \\
\text { p-stage I-IIla }\end{array}$ & $\begin{array}{c}31 \mathrm{SCC}, 17 \mathrm{AD}, 16 \mathrm{LA}, \\
3 \text { 0th }\end{array}$ & $\begin{array}{l}\leq 3.57 \\
>3.57\end{array}$ & $\begin{array}{l}62 \% \\
33 \%\end{array}$ & 0.014 \\
\hline Mizuguchi 2007 [17] & $\begin{array}{l}272 \text { NSCLC } \\
\text { p-stage I-IV }\end{array}$ & $\begin{array}{c}164 \mathrm{AD}, 99 \mathrm{SCC}, 5 \mathrm{LA}, \\
4 \mathrm{AD} / \mathrm{SCC}\end{array}$ & $\begin{array}{l}\leq 2 \\
>2\end{array}$ & $\begin{array}{l}\text { Multivariate analysis } \\
\text { HR } 2.42\end{array}$ & 0.015 \\
\hline Suzuki 2007 [16] & $\begin{array}{l}101 \text { NSCLC } \\
\text { c-Stage I }\end{array}$ & $\begin{array}{c}\text { AD 72, SCC 21, LA 7, } \\
\text { Oth } 1\end{array}$ & $\begin{array}{l}<3.5 \\
\geq 3.5\end{array}$ & $\begin{array}{l}83.3 \% \\
50 \%\end{array}$ & 0.006 \\
\hline Matsuoka 2007 [18] & $\begin{array}{l}275 \text { NSCLC } \\
\text { p-stage I }\end{array}$ & AD 193, SCC 71, oth 11 & $\begin{array}{l}\leq 2.8 \\
>2.8\end{array}$ & $\begin{array}{l}79.3 \% \\
64 \%\end{array}$ & 0.0041 \\
\hline Hanagiri 2011 [19] & $\begin{array}{l}264 \mathrm{AD} \\
\text { p-stage I }\end{array}$ & & $\begin{array}{l}\leq 2 \\
>2\end{array}$ & $\begin{array}{l}92.8 \% \\
75.4 \%\end{array}$ & 0.0001 \\
\hline Park 2013 [20] & $\begin{array}{c}298 \text { AD } \\
\text { p-stage I-III }\end{array}$ & & $\begin{array}{l}<1.95 \\
\geq 1.95\end{array}$ & $\begin{array}{l}79.1 \% \\
58.4 \%\end{array}$ & 0.001 \\
\hline
\end{tabular}

NSCLC — non -small cell lung cancer; p-stage — pathological stage of disease; c-stage — clinical stage of disease; AD — adenocarcinoma; SCC — squamous cell lung cancer; LA — large cell lung cancer; oth - others

Table 6. Prognostic value of carcinoembryonic antigen (CEA) according to published data

\begin{tabular}{|c|c|c|c|c|c|}
\hline Author & Study group & Histology & CEA cut off $\mathrm{ng} / \mathrm{mL}$ & 5-years survivors & $\mathbf{p}$ \\
\hline Suzuki 1999 [26] & $\begin{array}{l}365 \text { NSCLC } \\
\text { c-stage I }\end{array}$ & AD 267, oth 98 & $\begin{array}{l}<5 \\
\geq 5\end{array}$ & $\begin{array}{l}78.5 \% \\
53 \%\end{array}$ & 0.005 \\
\hline Sawabata 2002 [27] & $\begin{array}{l}297 \text { NSCLC } \\
\text { c-stage I }\end{array}$ & $\begin{array}{c}\text { AD 212, SCC 74, LA } \\
4 \text {, oth } 7\end{array}$ & $\begin{array}{l}\leq 7 \\
>7\end{array}$ & $\begin{array}{l}72 \% \\
49 \%\end{array}$ & 0.0001 \\
\hline Tomita 2004 [28] & $\begin{array}{c}271 \mathrm{AD} \\
\text { p-stage I-III }\end{array}$ & & $\begin{array}{l}\leq 5 \\
>5\end{array}$ & $\begin{array}{l}77.6 \% \\
42.5 \%\end{array}$ & 0.001 \\
\hline Okada 2004 [29] & $\begin{array}{l}1000 \text { NSCLC } \\
\text { C-stage I }\end{array}$ & $\begin{array}{c}694 \text { AD, } 260 \text { SCC, } 18 \\
\text { LA, } 28 \text { Oth }\end{array}$ & $\begin{array}{l}\leq 5 \\
>5\end{array}$ & $\begin{array}{l}75.2 \% \\
53.8 \%\end{array}$ & 0.0001 \\
\hline Fukai 2007 [30] & $\begin{array}{l}45 \text { NSCLC } \\
\text { p-stage II }\end{array}$ & $64 \% A D, 29 \% S C C$ & $\begin{array}{l}<5 \\
\geq 5\end{array}$ & $\begin{array}{l}79.9 \% \\
33.2 \%\end{array}$ & 0.0015 \\
\hline Matsuoka 2007 [18] & $\begin{array}{l}275 \text { NSCLC } \\
\text { p-stage I }\end{array}$ & $193 \mathrm{AD}, 71 \mathrm{SCC}, 11$ oth & $\begin{array}{l}\leq 5 \\
>5\end{array}$ & $\begin{array}{l}81.9 \% \\
59.8 \%\end{array}$ & 0.091 \\
\hline Kawachi 2009 [31] & $\begin{array}{l}815 \text { NSCLC } \\
\text { c-stage I }\end{array}$ & $\begin{array}{c}541 \mathrm{Ad}, 188 \mathrm{SCC}, 39 \\
\text { oth }\end{array}$ & $\begin{array}{r}<5 \\
5-30 \\
>30\end{array}$ & $\begin{array}{c}76.7 \% \\
60 \% \\
31.3 \%\end{array}$ & \\
\hline Igai 2012 [32] & $122 \mathrm{AD} p$-stage IA & & $\begin{array}{l}<5 \\
\geq 5\end{array}$ & $\begin{array}{l}93.3 \% \\
33.3 \%\end{array}$ & 0.0001 \\
\hline Kato 2013 [33] & $\begin{array}{c}141 \mathrm{AD} \\
\text { p-stage I }\end{array}$ & & $\begin{array}{l}\leq 2.5 \\
>2.5\end{array}$ & $\begin{array}{c}93 \% \\
59.4 \%\end{array}$ & 0.0001 \\
\hline
\end{tabular}

NSCLC — non -small cell lung cance; p-stage — pathological stage of disease; c-stage — clinical stage of disease; $A D$ - adenocarcinoma; SCC — squamous cell lung cancer; LA — large cell lung cancer; oth — others

On the other hand, Takahashi et al. [37], who examined CEA in 649 surgically treated patients, found that 7 out of 28 patients with serum CEA $>30 \mathrm{ng} / \mathrm{mL}$ were long-term survivors ( $>4$ years). This is similar to our observation that $6 / 11$ patients with CEA > $5 \mathrm{ng} / \mathrm{mL}$ survived 5 years or longer.

Important new data concerning the relation between high CEA serum concentration and the presence of EGFR mutation in adenocarcinoma were published in 2007 by Shoji et al. [38] and were recently confirmed by Zhang et al. [39].

\section{Summary}

In the present study, concerning surgically treated NSCLC patients with clinical stage I and II of the disease, a preoperative CRP value exceeding $10 \mathrm{mg} / \mathrm{L}$ and Cyfra 21-1 higher than $2 \mathrm{ng} / \mathrm{mL}$ were the only negative prognostic indicators. Patho- 
logical tumour size and p-stage of disease were significant postoperative prognostic indicators.

\section{Conflict of interest}

The authors declare no conflict of interest.

\section{References:}

1. Cho S., Song I.H., Yang H.C., Kim K., Jheon S. Predictive factors for node metastasis in patients with clinical stage I non -small cell lung cancer. Ann. Thorac. Surg 2013; 96: 239-246.

2. Darling G.E., Maziak D.E., Inculet R.I. et al. Positron emission tomography-computed tomography compared with invasive mediastinal staging in non-small cell lung cancer. J. Thorac. Oncol. 2011; 6: 1367-1372.

3. Chansky K., Sculier J-P., Crowley J.J., Giroux D., Van Meerbeeck J., Goldstraw P. The International Association for the Study of Lung Cancer Staging Project. Prognostic factors and pathologic TNM stage in surgically managed non-small cell lung cancer. J. Thorac. Oncol. 2009; 4: 792-801.

4. Tsuchiya T., Hashizume S., Akamine S. et al. Upstaging by vessel invasion improves the pathology staging system of non -small cell lung cancer. Chest 2007; 132: 170-177.

5. Travis W.D., Brambilla E., Muller-Hermelink H.K. et al. World Health Organisation classification of tumours. Pathology and genetics of tumour of the lung, pleura, thymus and heart. IARC, Lyon 2004.

6. UICC. TNM classification of malignant tumours $5^{\text {th }}$ and $6^{\text {th }}$ eds. Geneva: UICC, 1997 and 2002.

7. Quarck R., Nawrot T., Meyns B., Delcroix M. C-reactive protein. A new predictor of adverse outcome in pulmonary hypertension. JACC 2009; 53: 1211-1218.

8. Shields M.S., Pfeiffer R.M., Hildesheim A. et al. Circulating inflammation markers and prospective risk for lung cancer. J. Natl. Cancer Inst. 2013; 105: 1871-1880.

9. Ko Y-J., Kwon Y-M., Kim K.H. et al. High sensitivity C-reactive protein levels and cancer mortality. Cancer Epidemiol. Biomarkers Prev. 2012; 21: 2076-2086.

10. O’Dowd C., McRae L.A., McMillan D.C., Kirk A., Milroy R. Elevated preoperative C-reactive protein predicts poor cancer specific survival in patients undergoing resection for non-small cell lung cancer. J. Thorac. Oncol. 2010; 5: 988-992.

11. Hara M., Matsuzaki Y., Shimuzu T. et al. Preoperative serum C-reactive protein level in non-small cell lung cancer. Anticancer Res. 2007; 27: 3001-3004.

12. Tomita M., Shimizu T., Ayabe T., Nakamura K., Onitsuka T. Elevated preoperative inflammatory markers based on neutrophil-to-lymphocyte ratio and C-reactive protein predict poor survival in resected non-small cell lung cancer. Anticancer Res. 2012; 32: 3535-3538.

13. Alifano M., Falcoz P.E., Seegers V. et al. Preresection serum C-reactive protein measurement and survival among patients with resectable non-small cell lung cancer. J. Thorac. Cardiovasc. Surg. 2011; 142: 1161-1167.

14. Lee J.G., Cho B.C., Bae M.K. et al. Preoperative C-reactive protein levels are associated with tumour size and lymphovascular invasion in resected non-small cell lung cancer. Lung Cancer 2009; 63: 106-110.

15. Reinmuth N., Brandt B., Semik B. et al. Prognostic impact of Cyfra 21-1 and other serum markers in completely resected non-small cell lung cancer. Lung Cancer 2002; 36: 265-270.

16. Suzuki H., Ishikawa S., Satoh H. et al. Preoperative Cyfra 21-1 levels as a prognostic factor in c-stage I non-small cell lung cancer. Eur. J. Cardiothorac. Surg. 2007; 32: 648-652.

17. Mizuguchi S., Nishiyama N., Iwata T. et al. Clinical value of serum cytokeratin 19 fragment and sialyl-Lewis X in non-small cell lung cancer. Ann. Thorac. Surg. 2007; 83: 216-222.

18. Matsuoka K., Sumotomo S., Nakashima N., nakajima D., Misaki N. Prognostic value of carcinoembryonic antigen and Cyfra 21-1 in patients with pathological stage I non-small cell lung cancer. Eur. J. Cardiothorac. Surg. 2007; 32: 435-439.

19. Hanagiri T., Sugaya M., Takenaka M. et al. Preoperative Cyfra 21-1 and CEA as prognostic factors in patients with stage I non-small cell lung cancer. Lung Cancer 2011; 74: 112-117.
20. Park S.Y., Lee J.G., Kim J. et al. Preoperative serum Cyfra 21-1 level as a prognostic factor in surgically treated adenocarcinoma of lung. Lung Cancer 2013; 79: 156-160.

21. Takahashi H., Kurishima K., Ishikawa H., Kagohashi K., Kawaguchi M., Satoh H. Optimal cutoff of Cyfra 21-1 for survival prediction in non-small cell lung cancer patients based on running statistical analysis. Anticancer Res. 2010; 30: 3833-3838.

22. Szturmowicz M., Sakowicz A., Rudziński P. et al. The clinical value of Cyfra 21-1 estimation for lung cancer patients. Int. J. Biol. Markers 1996; 11: 172-177.

23. Rastel D., Ramaioli A., Cornillie F., Thirion B. Cyfra 21-1, a sensitive and specific new tumour marker for squamous cell lung cancer. Repotr of the first European Multicenter Evaluation. Eur. J. Cancer 1994; 30A: 601-606.

24. Kosacka M., Jankowska R. Comparison of cytokeratin 19 expression in tumour tissue and serum Cyfra 21-1 levels in non-small cell lung cancer. Pol. Arch. Med. Wewn. 2009; 119: 33-37.

25. Hanada S., Nishiyama N., Mizuguchi S. et al. Clinicopathological significance of combined analysis of cytokeratin 19 expression and preoperative serum Cyfra 21-1 levels in human lung squamous cell carcinoma. Osaka City Med. J. 2013; 59: 35-44.

26. Suzuki K., Nagai K., Yoshida J. et al. Prognostic factors in clinical stage I non-small cell lung cancer. Ann. Thorac. Surg. 1999; 67: 927-932.

27. Sawabata N., Ohta M., Takeda S. et al. Serum carcinoembryonic antigen level in surgically resected clinical stage I patients with non-small cell lung cancer. Ann. Thorac. Surg. 2002; 74: 174-179.

28. Tomita M., Matsuzaki Y., Edagawa M., Shimizu T., Hara M., Onitsuka T. Prognostic significance of preoperative serum carcinoembryonic antigen level in lung adenocarcinoma but not squamous cell carcinoma. Ann. Thorac. Cardiovasc. Surg. 2004; 10: 76-80.

29. Okada M., Nishio W., Sakamoto T. et al. Prognostic significance of perioperative serum carcinoembryonic antigen in non-small cell lung cancer: analysis of 1000 consecutive resections for clinical stage I disease. Ann. Thorac. Surg. 2004; 78: 216-221.

30. Fukai R., Sakao Y., Sakuraba M. et al. The prognostic value of carcinoembryonic antigen in T1N1M0 and T2N1M0 non-small cell carcinoma of the lung. Eur. J. Cardiothorac. Surg. 2007; 32: 440-444.

31. Kawachi R., Nakazato Y., Takei H., Koshi-ishi Y., Goya T. Clinical significance of preoperative carcinoembryonic antigen level for clinical stage I non-small cell lung cancer: can preoperative carcinoembryonic antigen level predict pathological stage? Interact. Cardiovasc. Thorac. Surg. 2009; 9: 199-202.

32. Igai H., Matsuura N., Tarumi S. et al. Prognostic factors in patients after lobectomy for p-T1aN0M0 adenocarcinoma. Eur. J. Cardiothorac. Surg. 2012; 41: 603-606.

33. Kato T., Ishikawa K., Aragaki M. et al. Optimal predictive value of preoperative serum carcinoembryonic antigen for surgical outcomes in stage I non-small cell lung cancer: differences according to histology and smoking status. J. Surg. Oncol. 2013; 107: 619-624.

34. Kozu Y., Maniwa T., Takahashi S., Isaka M., Ohde Y., Nakajima T. Prognostic significance of postoperative serum carcinoembryonic antigen levels in patients with completely resected pathological-stage I non-small cell lung cancer. J. Cardiothorac. Surg. 2013; 8: 106.

35. Ozeki N., Fukui T., Taniguchi T. et al. Significance of the serum carcinoembryonic antigen level during the follow up of patients with completely resected non-small cell lung cancer. Eur. J. Cardiothorac. Surg. 2013; Aug 26 (e-pub ahead of print).

36. Tomita M., Shimizu T., Ayabe T., Onitsuka T. Maximum SUV on positron emission tomography and serum CEA level as prognostic factors after curative resection for non-small cell lung cancer. Asia Pac. J. Clin. Oncol. 2012; 8: 244-247.

37. Takahashi N., Suzuki K., Takamochi K. Prognosis of surgically resected lung cancer with extremely high preoperative serum carcinoembryonic antigen level. Gen. Thorac. Cardiovasc. Surg. 2011; 59: 699-704.

38. Shoji F., Yoshino I., Yano T. et al. Serum carcinoembryonic antigen level is associated with epidermal growth factor receptor mutations in recurrent adenocarcinomas. Cancer 2007; 110: 2793-2798.

39. Zhang Y, Jin B., Shao M. Monitoring of carcinoembryonic antigen levels is predictictive of EGFR mutations and efficacy of EGFR-TKI in patients with lung adenocarcinoma. Tumour Biol. 2014, Jan 24 [ahead of print]. 